Transparency, openness, and reproducibility are readily recognized as vital features of science $(1,2)$. When asked, most scientists embrace these features as disciplinary norms and values (3). Therefore, one might expect that these valued features would be routine in daily practice. Yet, a growing body of evidence suggests that this is not the case (4-6).

\title{
POLICY
}

A likely culprit for this disconnect is an academic reward system that does not sufficiently incentivize open practices (7). In the present reward system, emphasis on innovation may undermine practices that support verification. Too often, publication requirements (whether actual or perceived) fail to encourage transparent, open, and reproducible science $(2,4,8,9)$. For example, in a transparent science, both null results and statistically significant results are made available and help others more accurately assess the evidence base for a phenomenon. In the present culture, however, null results are published less frequently than statistically significant results (10) and are, therefore, more likely inaccessible and lost in the "file drawer" (11).

The situation is a classic collective action problem. Many individual researchers lack strong incentives to be more transparent, even though the credibility of science would benefit if everyone were more transparent. Unfortunately, there is no centralized means of aligning individual and communal incentives via universal scientific policies and procedures. Universities, granting agencies, and publishers each create different incentives for researchers. With all of this complexity, nudging scientific practices toward greater openness requires complementary and coordinated efforts from all stakeholders.

*Corresponding author.nosek@virginia.edu.

Afliations for the authors, all of whom are members of the TOP Guidelines Committee, are given in the supplementary materials. 


\section{THE TRANSPARENCY AND OPENNESS PROMOTION GUIDELINES}

The Transparency and Openness Promotion (TOP) Committee met at the Center for Open Science in Charlottesville, Virginia, in November 2014 to address one important element of the incentive systems: journals' procedures and policies for publication. The committee consisted of disciplinary leaders, journal editors, funding agency representatives, and disciplinary experts largely from the social and behavioral sciences. By developing shared standards for open practices across journals, we hope to translate scientific norms and values into concrete actions and change the current incentive structures to drive researchers' behavior toward more openness. Although there are some idiosyncratic issues by discipline, we sought to produce guidelines that focus on the commonalities across disciplines.

Standards-There are eight standards in the TOP guidelines; each moves scientific communication toward greater openness. These standards are modular, facilitating adoption in whole or in part. However, they also complement each other, in that commitment to one standard may facilitate adoption of others. Moreover, the guidelines are sensitive to barriers to openness by articulating, for example, a process for exceptions to sharing because of ethical issues, intellectual property concerns, or availability of necessary resources. The complete guidelines are available in the TOP information commons at http://cos.io/top, along with a list of signatories that numbered 86 journals and 26 organizations as of 15 June 2015. The table provides a summary of the guidelines.

First, two standards reward researchers for the time and effort they have spent engaging in open practices. (i) Citation standards extend current article citation norms to data, code, and research materials. Regular and rigorous citation of these materials credit them as original intellectual contributions. (ii) Replication standards recognize the value of replication for independent verification of research results and identify the conditions under which replication studies will be published in the journal. To progress, science needs both innovation and self-correction; replication offers opportunities for self-correction to more efficiently identify promising research directions.

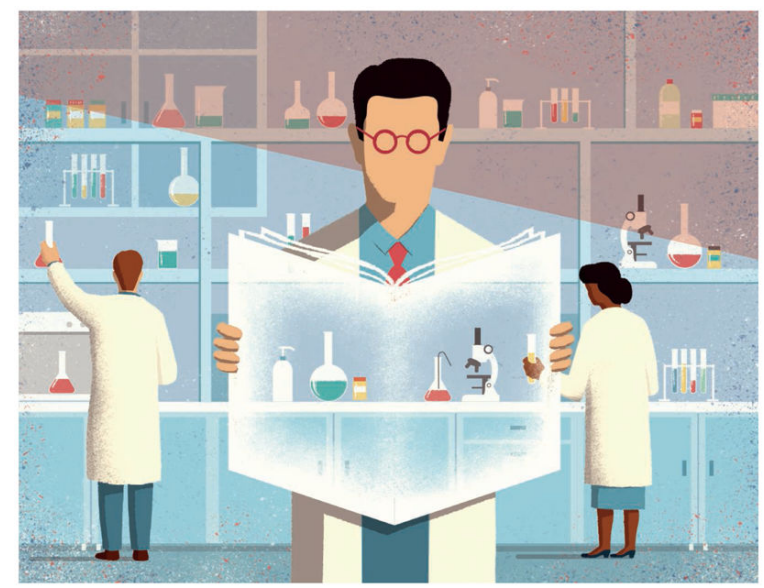

Second, four standards describe what openness means across the scientific process so that research can be reproduced and evaluated. Reproducibility increases confidence in results 
and also allows scholars to learn more about what results do and do not mean. (i) Design standards increase transparency about the research process and reduce vague or incomplete reporting of the methodology. (ii) Research materials standards encourage the provision of all elements of that methodology. (iii) Data sharing standards incentivize authors to make data available in trusted repositories such as Dataverse, Dryad, the Interuniversity Consortium for Political and Social Research (ICPSR), the Open Science Framework, or the Qualitative Data Repository. (iv) Analytic methods standards do the same for the code comprising the statistical models or simulations conducted for the research. Many discipline-specific standards for disclosure exist, particularly for clinical trials and health research more generally (e.g., www.equator-network.org). Many more are emerging for other disciplines, such as those developed by Psychological Science (12).

Finally, two standards address the values resulting from preregistration. (i) Standards for preregistration of studies facilitate the discovery of research, even unpublished research, by ensuring that the existence of the study is recorded in a public registry. (ii) Preregistration of analysis plans certify the distinction between confirmatory and exploratory research, or what is also called hypothesis-testing versus hypothesis-generating research. Making transparent the distinction between confirmatory and exploratory methods can enhance reproducibility $(3,13,14)$.

Levels-The TOP Committee recognized that not all of the standards are applicable to all journals or all disciplines. Therefore, rather than advocating for a single set of guidelines, the TOP Committee defined three levels for each standard. Level 1 is designed to have little to no barrier to adoption while also offering an incentive for openness. For example, under the analytic methods (code) sharing standard, authors must state in the text whether and where code is available. Level 2 has stronger expectations for authors but usually avoids adding resource costs to editors or publishers that adopt the standard. In Level 2, journals would require code to be deposited in a trusted repository and check that the link appears in the article and resolves to the correct location. Level 3 is the strongest standard but also may present some barriers to implementation for some journals. For example, the journals Political Analysis and Quarterly Journal of Political Science require authors to provide their code for review, and editors reproduce the reported analyses publication. In the table, we provide "Level 0" for comparison of common journal policies that do not meet the transparency standards.

Adoption-Defining multiple levels and distinct standards facilitates informed decisionmaking by journals. It also acknowledges the variation in evolving norms about research transparency. Depending on the discipline or publishing format, some of the standards may not be relevant for a journal. Journal and publisher decisions can be based on many factors —including their readiness to adopt modest to stronger transparency standards for authors, internal journal operations, and disciplinary norms and expectations. For example, in economics, many highly visible journals such as American Economic Review have already adopted strong policies requiring data sharing, whereas few psychology journals have comparable requirements. 
In this way, the levels are designed to facilitate the gradual adoption of best practices. Journals may begin with a standard that rewards adherence, perhaps as a step toward requiring the practice. For example, Psychological Science awards badges for "open data," "open materials," and "preregistration" (12), and approximately $25 \%$ of accepted articles earned at least one badge in the first year of operation.

The Level 1 guidelines are designed to have minimal effect on journal efficiency and workflow while also having a measurable impact on transparency. Moreover, although higher levels may require greater implementation effort up front, such efforts may benefit publishers and editors and the quality of publications by, for example, reducing time spent on communication with authors and reviewers, improving standards of reporting, increasing detectability of errors before publication, and ensuring that publication-related data are accessible for a long time.

Evaluation and revision-An information commons and support team at the Center for Open Science is available (top@ cos.io) to assist journals in selection and adoption of standards and will track adoption across journals. Moreover, adopting journals may suggest revisions that improve the guidelines or make them more flexible or adaptable for the needs of particular subdisciplines.

The present version of the guidelines is not the last word on standards for openness in science. As with any research enterprise, the available empirical evidence will expand with application and use of these guidelines. To reflect this evolutionary process, the guidelines are accompanied by a version number and will be improved as experience with them accumulates.

Conclusion-The journal article is central to the research communication process. Guidelines for authors define what aspects of the research process should be made available to the community to evaluate, critique, reuse, and extend. Scientists recognize the value of transparency, openness, and reproducibility. Improvement of journal policies can help those values become more evident in daily practice and ultimately improve the public trust in science, and science itself.

\section{Supplementary Material}

Refer to Web version on PubMed Central for supplementary material.

\section{ACKNOWLEDGMENTS}

This work was supported by the Laura and John Arnold Foundation.

\section{REFERENCES}

1. McNutt M. Science. 2014; 343:229. [PubMed: 24436391]

2. Miguel E, et al. Science. 2014; 343:30. [PubMed: 24385620]

3. Anderson MS, Martinson BC, De Vries R. J. Empir. Res. Hum. Res. Ethics. 2007; 2:3. [PubMed: 19385804] 
4. Ioannidis JPA, Munafò MR, Fusar-Poli P, Nosek BA, David SP. Trends Cogn. Sci. 2014; 18:235. [PubMed: 24656991]

5. John LK, Loewenstein G, Prelec D. Psychol. Sci. 2012; 23:524. [PubMed: 22508865]

6. O’Boyle EH Jr. Banks GC, Gonzalez-Mule E. J. Manage. 2014 10.1177/0149206314527133.

7. Nosek BA, Spies JR, Motyl M. Perspect. Psychol. Sci. 2012; 7:615. [PubMed: 26168121]

8. Asendorpf JB, et al. Eur. J. Pers. 2013; 27:108.

9. Simmons JP, Nelson LD, Simonsohn U. Psychol. Sci. 2011; 22:1359. [PubMed: 22006061]

10. Franco A, Malhotra N, Simonovits G. Science. 2014; 345:1502. [PubMed: 25170047]

11. Rosenthal R. Psychol. Bull. 1979; 86:638.

12. Eich E. Psychol. Sci. 2014; 25:3. [PubMed: 24285431]

13. Wagenmakers E-J, Wetzels R, Borsboom D, van der Maas HL, Kievit RA. Perspect. Psychol. Sci. 2012; 7:632. [PubMed: 26168122]

14. Chambers CD. Cortex. 2013; 49:609. [PubMed: 23347556] 
Summary of the eight standards and three levels of the TOP guidelines

LEVEL 0

\begin{tabular}{|c|c|c|c|c|}
\hline Citation standards & $\begin{array}{l}\text { Journal encourages } \\
\text { citation of data, code, } \\
\text { and materials-or says } \\
\text { nothing. }\end{array}$ & $\begin{array}{l}\text { Journal describes } \\
\text { citation of data in } \\
\text { guidelines to authors } \\
\text { with clear rules and } \\
\text { examples. }\end{array}$ & $\begin{array}{l}\text { Article provides appropriate } \\
\text { citation for data and } \\
\text { materials } \\
\text { used, consistent with } \\
\text { journal's } \\
\text { author guidelines. }\end{array}$ & $\begin{array}{l}\text { Article is not published until } \\
\text { appropriate citation for data } \\
\text { and materials is provided that } \\
\text { follows journal's author } \\
\text { guidelines. }\end{array}$ \\
\hline Data transparency & $\begin{array}{l}\text { Journal encourages } \\
\text { data sharing-or says } \\
\text { nothing. }\end{array}$ & $\begin{array}{l}\text { Article states whether } \\
\text { data are available and, } \\
\text { if so, where to access } \\
\text { them. }\end{array}$ & $\begin{array}{l}\text { Data must be posted to a } \\
\text { trusted repository. } \\
\text { Exceptions } \\
\text { must be identified at article } \\
\text { submission. }\end{array}$ & $\begin{array}{l}\text { Data must be posted to a } \\
\text { trusted repository, and } \\
\text { reported analyses will be } \\
\text { reproduced independently } \\
\text { before publication. }\end{array}$ \\
\hline $\begin{array}{l}\text { Analytic methods } \\
\text { (code) transparency }\end{array}$ & $\begin{array}{l}\text { Journal encourages } \\
\text { code sharing-or says } \\
\text { nothing. }\end{array}$ & $\begin{array}{l}\text { Article states whether } \\
\text { code is available and, if } \\
\text { so, where to access } \\
\text { them. }\end{array}$ & $\begin{array}{l}\text { Code must be posted to a } \\
\text { trusted repository. } \\
\text { Exceptions } \\
\text { must be identified at article } \\
\text { submission. }\end{array}$ & $\begin{array}{l}\text { Code must be posted to a } \\
\text { trusted repository, and } \\
\text { reported analyses will be } \\
\text { reproduced independently } \\
\text { before publication. }\end{array}$ \\
\hline $\begin{array}{l}\text { Research materials } \\
\text { transparency }\end{array}$ & $\begin{array}{l}\text { Journal encourages } \\
\text { materials sharing-or says } \\
\text { nothing }\end{array}$ & $\begin{array}{l}\text { Article states whether } \\
\text { materials are available } \\
\text { and, if so, where to } \\
\text { access them. }\end{array}$ & $\begin{array}{l}\text { Materials must be posted to } \\
\text { a } \\
\text { trusted repository. } \\
\text { Exceptions } \\
\text { must be identified at article } \\
\text { submission. }\end{array}$ & $\begin{array}{l}\text { Materials must be posted to a } \\
\text { trusted repository, and } \\
\text { reported analyses will be } \\
\text { reproduced independently } \\
\text { before publication. }\end{array}$ \\
\hline $\begin{array}{l}\text { Design and analysis } \\
\text { transparency }\end{array}$ & $\begin{array}{l}\text { Journal encourages } \\
\text { design and analysis } \\
\text { transparency or says } \\
\text { nothing. }\end{array}$ & $\begin{array}{l}\text { Journal articulates } \\
\text { design transparency } \\
\text { standards. }\end{array}$ & $\begin{array}{l}\text { Journal requires adherence } \\
\text { to } \\
\text { design transparency } \\
\text { standards } \\
\text { for review and publication. }\end{array}$ & $\begin{array}{l}\text { Journal requires and enforces } \\
\text { adherence to design transpar- } \\
\text { ency standards for review and } \\
\text { publication. }\end{array}$ \\
\hline $\begin{array}{l}\text { Preregistration } \\
\text { of studies }\end{array}$ & Journal says nothing. & $\begin{array}{l}\text { Journal encourages } \\
\text { preregistration of } \\
\text { studies and provides } \\
\text { link in article to } \\
\text { preregistration if it } \\
\text { exists. }\end{array}$ & $\begin{array}{l}\text { Journal encourages preregis- } \\
\text { tration of studies and } \\
\text { provides } \\
\text { link in article and } \\
\text { certification } \\
\text { of meeting preregistration } \\
\text { badge requirements. }\end{array}$ & $\begin{array}{l}\text { Journal requires } \\
\text { preregistration } \\
\text { of studies and provides link } \\
\text { and } \\
\text { badge in article to meeting } \\
\text { requirements. }\end{array}$ \\
\hline $\begin{array}{l}\text { Preregistration } \\
\text { of analysis plans }\end{array}$ & Journal says nothing. & $\begin{array}{l}\text { Journal encourages } \\
\text { preanalysis plans and } \\
\text { provides link in article } \\
\text { to registered analysis } \\
\text { plan if it exists. }\end{array}$ & $\begin{array}{l}\text { Journal encourages } \\
\text { preanaly- } \\
\text { sis plans and provides link } \\
\text { in } \\
\text { article and certification of } \\
\text { meeting registered analysis } \\
\text { plan badge requirements. }\end{array}$ & $\begin{array}{l}\text { Journal requires } \\
\text { preregistration } \\
\text { of studies with analysis plans } \\
\text { and provides link and badge } \\
\text { in } \\
\text { article to meeting } \\
\text { requirements. }\end{array}$ \\
\hline Replication & $\begin{array}{l}\text { Journal discourages } \\
\text { submission of } \\
\text { replication studies-or } \\
\text { says nothing. }\end{array}$ & $\begin{array}{l}\text { Journal encourages } \\
\text { submission of } \\
\text { replication studies. }\end{array}$ & $\begin{array}{l}\text { Journal encourages submis- } \\
\text { sion of replication studies } \\
\text { and } \\
\text { conducts blind review of } \\
\text { results. }\end{array}$ & $\begin{array}{l}\text { Journal uses Registered } \\
\text { Reports as a submission } \\
\text { option } \\
\text { for replication studies with } \\
\text { peer } \\
\text { review before observing the } \\
\text { study outcomes. }\end{array}$ \\
\hline
\end{tabular}

Levels 1 to 3 are increasingly stringent for each standard. Level 0 offers a comparison that does not meet the standard. 